\title{
Deep-ocean, sediment-dwelling animals are sensitive to sequestered carbon dioxide
}

\author{
D. Thistle ${ }^{1, *}$, K. R. Carman ${ }^{2}$, L. Sedlacek1 ${ }^{1}$ P. G. Brewer ${ }^{3}$, J. W. Fleeger ${ }^{2}$, J. P. Barry ${ }^{3}$ \\ ${ }^{1}$ Department of Oceanography, Florida State University, Tallahassee, Florida 32306-4320, USA \\ ${ }^{2}$ Department of Biological Sciences, Louisiana State University, Baton Rouge, Louisiana 70803-1725, USA \\ ${ }^{3}$ Monterey Bay Aquarium Research Institute, Sandholdt Road, Moss Landing, California 95039, USA
}

\begin{abstract}
The burning of fossil fuel is producing the greenhouse gas $\mathrm{CO}_{2}$ at a rate that is causing global warming and threatens to change the global environment adversely. One proposed solution involves sequestering in the deep sea a substantial portion of the excess $\mathrm{CO}_{2}$ produced. Because large areas would be affected and this environment harbors one of the world's largest reservoirs of biodiversity, the approach is controversial. In particular, deep-sea diversity is found largely in the animals that live in the sediment, but the effects of sequestered $\mathrm{CO}_{2}$ on these organisms are not known. We therefore introduced $\sim 60 \mathrm{l}$ of liquid $\mathrm{CO}_{2}$ onto the seafloor at $3250 \mathrm{~m}$ depth and sampled $\sim 2$ and $\sim 40 \mathrm{~m}$ from the deposition site $30 \mathrm{~d}$ later. The pore water in the samples taken near the site was $0.75 \mathrm{pH}$ unit more acidic ( $\mathrm{pH}$ decreases when $\mathrm{CO}_{2}$ concentration increases) than that in samples taken farther away. Representative infauna had been killed in significantly greater numbers in the former than in the latter location. This demonstration that sequestered $\mathrm{CO}_{2}$ can adversely affect the deep-sea infauna brings $\mathrm{CO}_{2}$ sequestration in the deep sea into potential conflict with the preservation of deep-sea biodiversity.
\end{abstract}

KEY WORDS: · Global warming $\cdot \mathrm{CO}_{2}$ sequestration $\cdot$ Deep sea $\cdot$ Benthic infauna $\cdot$ Harpacticoid copepods · Diversity

Resale or republication not permitted without written consent of the publisher

\section{INTRODUCTION}

Since the beginning of the industrial revolution, the concentration of $\mathrm{CO}_{2}$ in the atmosphere has increased from 275 parts per million (ppm) to $370 \mathrm{ppm}$ (Hoffert et al. 2002), and it continues to increase by $\sim 1.5 \mathrm{ppm} \mathrm{yr}^{-1}$ (Herzog et al. 2000). Because $\mathrm{CO}_{2}$ is a 'greenhouse' gas, the increasing concentration will exacerbate global warming. The ocean has a large capacity to absorb $\mathrm{CO}_{2}$ and is being considered as a reservoir in which $\mathrm{CO}_{2}$ could be sequestered (Glover \& Smith 2003, Tyler 2003).

One strategy involves the collection of $\mathrm{CO}_{2}$ before it enters the atmosphere and its injection into the deep ocean (Ormerod et al. 2002). Because large areas would be affected and the deep sea harbors one of the world's greatest reservoirs of biodiversity (Hessler \& Sanders 1967, Grassle \& Maciolek 1992, but see Lambs- head \& Boucher 2003), the approach is controversial. In particular, the bulk of metazoan biodiversity is concentrated in the invertebrate infauna (e.g. polychaete worms, bivalve mollusks, nematode worms, harpacticoid copepods; Lambshead 1993), but the ecological effects of sequestered $\mathrm{CO}_{2}$ on these organisms are unknown (Glover \& Smith 2003, Tyler 2003). Here, we present results of an experiment that examined the ecological effects of sequestered $\mathrm{CO}_{2}$ on the infauna.

\section{MATERIALS AND METHODS}

At $3250 \mathrm{~m}$ depth off Monterey, CA, USA $\left(36^{\circ} 22.8^{\prime} \mathrm{N}\right.$, $122^{\circ} 40.7^{\prime} \mathrm{W}$ ), we transported $\mathrm{CO}_{2}$ to the seabed with the remotely operated vehicle 'Tiburon' of the Monterey Bay Aquarium Research Institute and pumped approximately $20 \mathrm{l}$ of liquid $\mathrm{CO}_{2}$ into each of three 
$48 \mathrm{~cm}$ diameter by $20 \mathrm{~cm}$ long plastic pipe segments ('corrals'), which had been set vertically into the seabed such that each formed a ring that extended $\sim 10 \mathrm{~cm}$ into the overlying water. The liquid $\mathrm{CO}_{2}$ was denser than seawater at this depth and formed a pool in each corral (Fig. 1). Thirty days later, we collected sediment cores $(7 \mathrm{~cm}$ inner diameter) from an area $\sim 2 \mathrm{~m}$ away from a corral (a region expected to have been exposed to $\mathrm{CO}_{2}$-rich seawater) and from an area $\sim 40 \mathrm{~m}$ away from the nearest corral, which should not have been influenced by the $\mathrm{CO}_{2}$ additions (Fig. 2).

Because $\mathrm{CO}_{2}$ concentration is difficult to measure at the spatial resolution we required, we used $\mathrm{pH}$ as a surrogate, as has been done in previous experimental

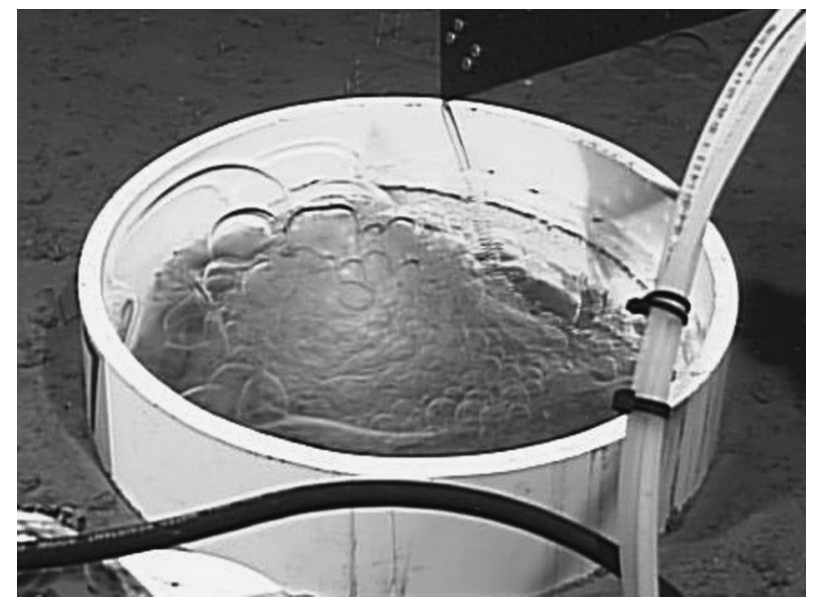

Fig. 1. The remotely operated vehicle 'Tiburon' filling a PVC corral (diameter $=48 \mathrm{~cm}$ ) with liquid $\mathrm{CO}_{2}$ at $3250 \mathrm{~m}$ depth off Monterey, CA, USA

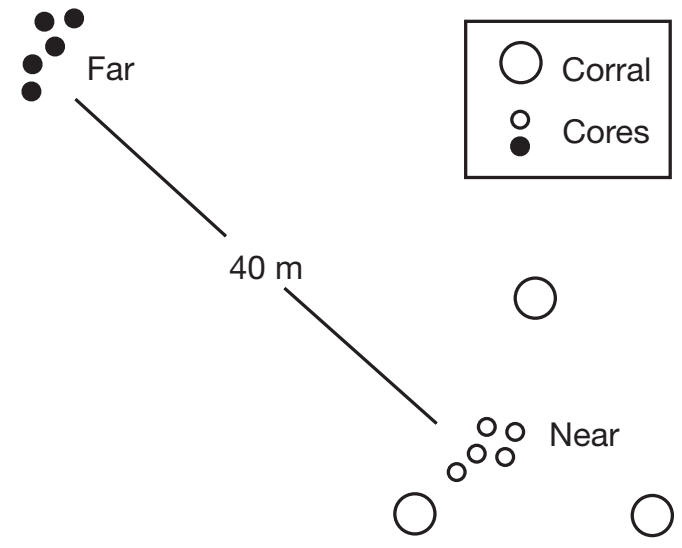

Fig. 2. Sketch (not to scale) of the sampling site, showing the relative positions of the corrals filled with $\mathrm{CO}_{2}$, the locations cored $30 \mathrm{~d}$ later near the corrals in an area exposed to $\mathrm{CO}_{2}-$ rich seawater, and the locations cored far from the corrals in an area not exposed to $\mathrm{CO}_{2}$-rich seawater. Corrals were separated by $\sim 10 \mathrm{~m}$ work on $\mathrm{CO}_{2}$ sequestration (Tamburri et al. 2000). Changes in $\mathrm{CO}_{2}$ concentration change $\mathrm{pH}$ through the $\mathrm{CO}_{2}+\mathrm{H}_{2} \mathrm{O} \leftrightarrow \mathrm{H}_{2} \mathrm{CO}_{3} \leftrightarrow \mathrm{H}^{+}+\mathrm{HCO}_{3}^{-} \leftrightarrow 2 \mathrm{H}^{+}+$ $\mathrm{CO}_{3}{ }^{2-}$ equilibrium. We measured $\mathrm{pH}$ profiles in recovered cores using a Unisense ${ }^{\circledR}$ microelectrode (tip diameter $=100 \mu \mathrm{m}$ ) and an externally calibrated Knick $^{\circledR}$ Portamess 913 pH meter. The microelectrode was mounted on a micromanipulator, and measurements were made at $250 \mu \mathrm{m}$ intervals.

To test for effects on the infaunal invertebrates, we chose harpacticoid copepods as a representative taxon. These miniature crustaceans (body length $<1 \mathrm{~mm}$, dry weight $<5 \mu \mathrm{g}$ ) are ubiquitous and abundant in sediment, and one can assess the condition of their internal organs by inspection through their transparent body walls.

So as to be able to determine whether individuals in our necessarily preserved samples had been dead or alive at the time of collection, we did a preliminary study. Two lots of 100 laboratory-cultured adults of the shallow-water harpacticoid copepod species Amphiascoides atopus Lotufo and Fleeger were killed by freezing because logistic limitations precluded their exposure to high concentrations of $\mathrm{CO}_{2}$. One lot was exposed at our study site for $1 \mathrm{~d}$ and the second for $30 \mathrm{~d}$ before the specimens were preserved in formaldehyde. An investigator who did not know the origin of the specimen then examined each adult harpacticoid in lateral view under a compound microscope and scored the condition of its internal organs. From the results, we devised a 2-state criterion based on striated-muscle appearance by which specimens alive or very recently dead when collected could be reliably distinguished from specimens that had been dead for many days. This approach assumed that the striated muscles of specimens of A. atopus and the deep-sea species at our site were in similar condition when preserved alive. We made this assumption because, in previous work, we have examined many specimens from both shallow water and the deep sea that had been preserved alive and have found that their striated muscles were in comparable condition.

\section{RESULTS}

When we returned after $30 \mathrm{~d}$, no $\mathrm{CO}_{2}$ was visible in the corrals or on the seabed adjacent to them. (Liquid $\mathrm{CO}_{2}$ could be seen because its refractive index differs from that of seawater, Fig. 1.) The $\mathrm{pH}$ profiles revealed that, on average, the pore water of cores taken near a corral was $\sim 0.75 \mathrm{pH}$ unit more acidic than that of cores taken far from corrals and that the profiles from the 2 groups of cores did not overlap (Fig. 3). 


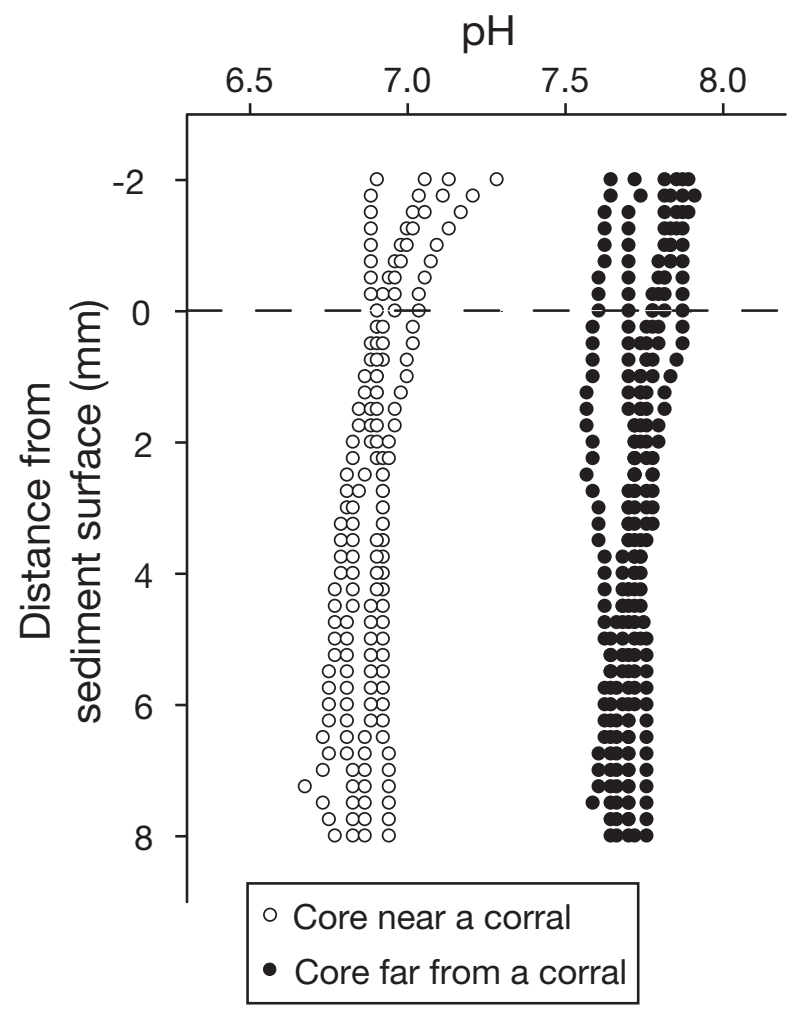

Fig. 3. Profiles of $\mathrm{pH}$ from $2 \mathrm{~mm}$ above the sediment surface to $8 \mathrm{~mm}$ below showing that the $\mathrm{pH}$ in the cores from near $(\sim 2 \mathrm{~m})$ the corrals was lower than that in those taken far $(\sim 40 \mathrm{~m})$ from the corrals

\section{Proportion collected 'alive'}

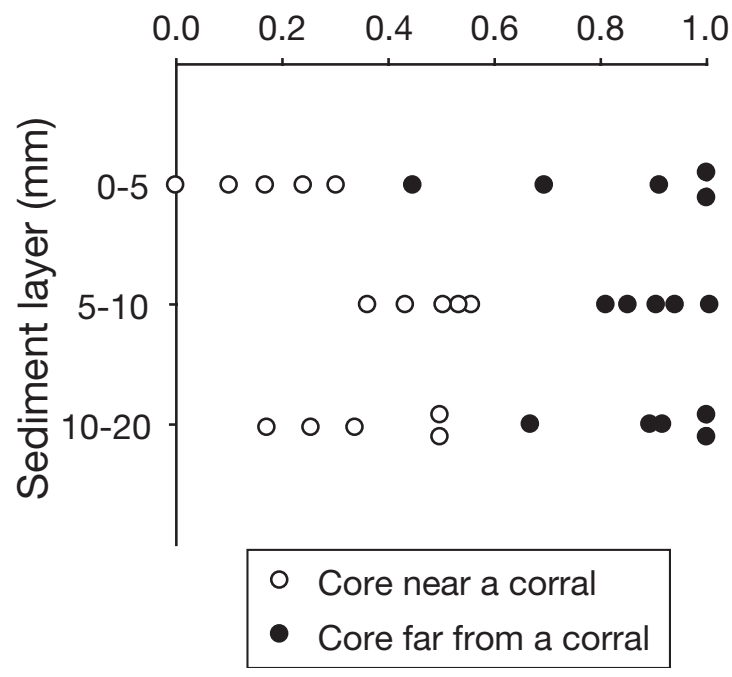

Fig. 4. Average proportion of adult harpacticoids that were 'alive' at the time of collection in samples from 3 sediment horizons, showing that a lower proportion were 'alive' at the time of collection in samples taken near $(\sim 2 \mathrm{~m})$ the corrals than in samples taken far $(\sim 40 \mathrm{~m})$ from the corrals. When 2 corrals had the same value, their points were plotted one above the other. Our definition of 'alive' is given in the text
For each of 3 sediment layers, the proportion of the individuals scored by our 2-state criterion as 'alive' when collected was significantly lower in the samples taken near the corrals than in samples taken far from the corrals (Fig. 4, p < 0.003, 2-tailed test, resampling statistics, Simon 1999).

\section{DISCUSSION}

Although the lack of a vertical gradient in our porewater $\mathrm{pH}$ profiles revealed that some mixing had occurred during recovery and handling, the pore water was consistently more acidic in the cores taken near the corrals than in those taken farther away. The difference was far greater than reported natural variability ( $0.1 \mathrm{pH}$ unit, Ormerod et al. 2002) or the variability among profiles from the cores collected far from the corrals (Fig. 3). We infer that $\mathrm{CO}_{2}$ dissolved into the near-bottom water and that $\mathrm{CO}_{2}$-rich seawater flowed out of the corrals and across the surrounding seabed. Near the corrals, it reduced the $\mathrm{pH}$ of the pore waters. We infer that, $40 \mathrm{~m}$ from its source, it was much diluted and that, if it affected the $\mathrm{pH}$ of the pore water, the effect was much less than that near the source. Whatever the mechanism, we succeeded in subjecting infaunal organisms to different $\mathrm{CO}_{2}$ concentrations.

Although relatively little is known about the effects of elevated $\mathrm{CO}_{2}$ concentrations or reduced $\mathrm{pH}$ on them, deep-sea animals are adapted to stable $\mathrm{CO}_{2}$ concentrations and $\mathrm{pH}$ and have much less buffering capacity than do shallow-water species. Even slight changes in $\mathrm{pH}$ are thought to have important influences on metabolic activities (Seibel \& Walsh 2003), and acidification has been shown to extirpate an invertebrate population in a lake (France \& Collins 1993). Our results suggest that exposure to $\mathrm{CO}_{2}$-rich seawater resulted in the deaths of many harpacticoids and presumably other infauna. Because the intensity of exposure to $\mathrm{CO}_{2}$-rich seawater was unlikely to have been constant during the $30 \mathrm{~d}$ between injection and sampling, we do not know the dose and duration that caused the deaths.

From the same experiment we describe here, Carman et al. (2004) showed that exposure to $\mathrm{CO}_{2}$-rich seawater did not influence total abundances or vertical distributions of benthic invertebrate taxa. Only by closer examination of harpacticoid condition were we able to detect an effect of $\mathrm{CO}_{2}$ exposure.

Determination of the environmental effects of $\mathrm{CO}_{2}$ sequestration on infaunal species will require both a quantitative understanding of how death and illness relate to exposure to $\mathrm{CO}_{2}$-rich seawater and knowledge of the spatial extent of the effects. In particular, if the areas in which mortality approaches $100 \%$ are 
similar in size to the geographic ranges of deep-sea infaunal species, sequestration could result in species extinctions and the reduction of deep-sea biodiversity. This scenario is plausible because many deep-sea species appear to have small geographic ranges (Grassle \& Maciolek 1992).

Acknowledgements. K. R. Buck, L. Kuhnz, E. T. Peltzer, P. J. Whaling, and the personnel of the RV 'Western Flyer' and the ROV 'Tiburon' helped us in the field. The comments of A. B. Thistle and 2 anonymous reviewers improved the manuscript. We are grateful for this kind help. This research was supported by the Office of Science (BER), U.S. Department of Energy, Grant No. DE-FG02-02ER63456.

\section{LITERATURE CITED}

Carman KR, Thistle D, Fleeger JW, Barry JP (2004) The influence of introduced $\mathrm{CO}_{2}$ on deep-sea metazoan meiofauna. J Oceanogr 60:767-772

France RL, Collins NC (1993) Extirpation of crayfish in a lake affected by long-range anthropogenic acidification. Conserv Biol 7:184-188

Glover AG, Smith SR (2003) The deep-sea floor ecosystem: current status and prospectus of anthropogenic change by the year 2025. Environ Conserv 30:219-241

Editorial responsibility: Kenneth Heck (Contributing Editor), Dauphin Island, Alabama, USA
Grassle JF, Maciolek NJ (1992) Deep-sea species richness: regional and local diversity estimates from quantitative bottom samples. Am Nat 139:313-341

Herzog H, Eliasson B, Kaarstad O (2000) Capturing greenhouse gases. Sci Am 282(2):72-77, 79

Hessler RR, Sanders HL (1967) Faunal diversity in the deep sea. Deep-Sea Res 14:65-78

Hoffert MI, Caldeira K, Benford G, Criswell DR and 14 others (2002) Advanced technology paths to global climate stability: energy for a greenhouse planet. Science 298: 981-987

Lambshead PJD (1993) Recent developments in marine benthic biodiversity research. Océanis 19:5-24

Lambshead PJD, Boucher G (2003) Marine nematode deepsea biodiversity-hyperdiverse or hype? J Biogeogr 30: $475-485$

Ormerod WG, Freund P, Smith A (2002) Ocean storage of $\mathrm{CO}_{2}$, 2nd edn. IEA Greenhouse Gas R\&D Programme, Cheltenham

Seibel BA, Walsh PJ (2003) Biological impacts of deep-sea carbon dioxide injection inferred from indices of physiological performance. J Exp Biol 206:641-650

Simon JL (1999) Resampling: the new statistics. Resampling Stats, Arlington, VA

Tamburri MN, Peltzer ET, Friedrich GE, Aya I, Yamane K, Brewer PG (2000) A field study of the effects of $\mathrm{CO}_{2}$ ocean disposal on mobile deep-sea animals. Mar Chem 72:95-101

Tyler PA (2003) Disposal in the deep sea: analogue of nature or faux ami? Environ Conserv 30:26-39

Submitted: May 6, 2004; Accepted: December 2, 2004

Proofs received from author(s): March 16, 2005 